\title{
BEHAVIOURAL AND CHEMICAL STUDIES OF DISCRIMINATION PROCESSES IN THE LEAF-CUTTING ANT Acromyrmex laticeps nigrosetosus (FOREL, 1908)
}

\author{
SOUZA, D. J. ${ }^{1}$, DELLA LUCIA, T. M. C. ${ }^{1}$, ERRARD, C. ${ }^{2}$, RICHARD, F-J. ${ }^{2}$ and LIMA, E. R. ${ }^{1}$ \\ ${ }^{1}$ Departamento de Biologia Animal, Universidade Federal de Viçosa, CEP 36570-000, Viçosa, MG, Brazil \\ ${ }^{2}$ Institut de Recherche sur la Biologie de l'Insecte, CNRS UMR 6035, Université de Tours, France \\ Correspondence to: Terezinha Maria Castro Della Lucia, Departamento de Biologia Animal, \\ Universidade Federal de Viçosa, CEP 36570-000, Viçosa, MG, Brazil, e-mail: tdlucia@ufv.br
}

Received May 24, 2004 - Accepted August 11, 2004 - Distributed August 31, 2006

(With 5 figures)

\begin{abstract}
Leaf-cutting ants live in symbiosis with a basidiomycete fungus that is exploited as a source of nutrients for ant larvae. Tests of brood transport revealed that Acromyrmex laticeps nigrosetosus workers did not discriminate a concolonial brood from an alien brood. The same result was observed with tests of fungus transport. Adult workers showed no aggressive behaviour to workers from other alien colonies (non-nestmates). There was no qualitative variation in the chemical profiles of larvae, pupae and adult workers from the different colonies. However, quantitative differences were observed between the different colonies. Hypotheses about the lack of intraspecific aggression in this subspecies of ants are discussed.
\end{abstract}

Keywords: leaf-cutting ants, intraspecific aggressiveness, chemical profiles, brood discrimination, fungus discrimination.

\section{RESUMO}

\section{Estudos químico e comportamental dos processos discriminatórios na formiga cortadeira Acromyrmex laticeps nigrosetosus (Forel, 1908)}

As formigas cortadeiras vivem em simbiose com um fungo basidiomiceto que é utilizado como fonte de nutriente para suas larvas. Testes de transporte de prole revelaram que as operárias de Acromyrmex laticeps nigrosetosus não discriminaram a prole concolonial de prole estranha. $\mathrm{O}$ mesmo resultado foi verificado com testes de transporte do fungo. As operárias adultas não exibiram comportamento agressivo frente a operárias de outras colônias (não companheiras de ninho). Não houve variação qualitativa nos perfis químicos de larvas, pupas e operárias adultas de diferentes colônias. No entanto, diferenças quantitativas foram observadas entre as diferentes colônias. Hipóteses sobre a ausência de agressão intra-específica nesta subespécie de formiga são discutidas.

Palavras-chave: formigas cortadeiras, agressividade intraespecífica, perfis químicos, discriminação de prole, discriminação de fungo.

\section{INTRODUCTION}

The ability to recognize kin is widespread, and especially important in highly social organisms (Stuart \& Herbers, 2000). This capacity to recognize nestmates and to distinguish them from nonnestmates is based on each colony having its own "chemical signature", a specific and characteristic chemical cue mixture for each colony (Hölldobler
\& Michener, 1980). Nestmate recognition in ants is defined by the ability of workers to discriminate members from allocolonial among conspecifics (Vander Meer \& Morel, 1998). Different methods of recognition, based on the origin of the colony odour (environment and pheromones produced by each individual or by the queen), are detected in ant societies (Whitehouse \& Jaffé, 1995). It is generally 
accepted that cuticular hydrocarbons $(\mathrm{CH})$ play an important role in nestmate recognition (Lahav et al., 1999). The harvester ants Pogonomyrmex barbatus can perceive different $\mathrm{CH}$ variations and can use these differences in nestmate recognition (Wagner et al., 2000). In Camponotus fellah, social isolation induced a divergence of the individual hydrocarbon profiles (Boulay et al., 2000). Intolerance towards isolated $C$. fellah workers starts after about 10-20 days, the time necessary for the $\mathrm{CHs}$ to change and assume individual profiles distinct from the colony profile (Boulay et al., 2000). These authors determined that individual hydrocarbon production is dynamic; workers must exchange hydrocarbons continually (mainly by trophallaxis) to maintain colonial odour. This is referred to as the Gestalt odour, a mixture of odours from each individual in the colony and odours from the environment (Crozier \& Dix, 1979). Since individual $\mathrm{CH}$ production is dynamic, it is essential for nestmates to homogenize their chemical cues often to create a uniform colony-specific profile (Vander Meer et al., 1989). The uniformity of the chemical profiles results from this constant homogenization of chemical cues produced by all colony members. Ant's species that do not use trophallaxis, exchange their chemical cues by social contacts or allogrooming. Experiments on the nontrophallactic ant Pachycondyla apicalis showed that physical contacts, as well as allogrooming are able to maintain a uniform colony odour (Soroker et al., 1998). On the other hand, Lenoir et al. (2001) suggested that allogrooming is an important behaviour for effective cue transfer in the nontrophallactic ant Aphaenogaster senilis.

Colony brood recognition has also been demonstrated in several ant species. The concolonial brood is accepted and nourished by workers, while an allocolonial brood may be rejected (BonavitaCougourdan et al., 1989; Bonavita-Cougourdan et al., 1993). In fact, the brood possesses chemical cues that enable workers to recognize it (Araújo et al., 1996; Viana et al., 2001).

Leaf cutting ants live in symbiosis with a basidiomycete fungus that is exploited as a source of nutrients for ant larvae. In Atta cephalotes, there is some evidence that a nestmate brood is distinguished (Robinson \& Cherrett, 1974). Workers of A. sexdens rubropilosa rejected allocolonial larvae and pupae, as well as eggs when they were directly removed from the fungus garden, but did not reject eggs directly obtained from previously isolated queens (Araújo et al., 1996). In Acromyrmex octospinosus, workers are able to recognize their concolonial brood (Febvay et al., 1984). In Ac. subterraneus subterraneus workers can discriminate concolonial fungus from alien fungus (Viana et al., 2001) and in this subspecies, a chemical analysis of the brood revealed a great similarity between its brood profile and on the fungus.

The objective of this study is to evaluate behavioural responses of workers from Acromyrmex laticeps nigrosetosus to concolonial or allocolonial larvae, pupae and adults. This research also aims to establish the cuticular chemical profiles of brood and adults of this ant subspecies and their implications on behaviour. The worker response to either concolonial or allocolonial fungus was also tested.

\section{MATERIAL AND METHODS}

\section{Collection of ants and rearing conditions}

In one leaf-cutting ant survey under eucalyptus stands in the region of Paraopeba, Minas Gerais (19 $17^{\prime} \mathrm{S}$ and $44^{\circ} 29^{\prime} \mathrm{W} ; 700 \mathrm{~m}$ altitude), Araújo et al. (1997) observed high frequencies and densities of Acromyrmex laticeps nigrosetosus nests throughout the year. These nests were underground, but superficial since they were located at $0.11 \mathrm{~m}$ below the soil surface and each nest generally consisted of a single chamber.

Behavioural and chemical tests were conducted with workers from Ac. laticeps nigrosetosus colonies. These colonies were collected at Paraopeba, Minas Gerais state (Brazil) 2 years before starting the experiment. They were established in the laboratory and consisted of approximately 3,000-4,000 individuals and numerous broods; the fungus volume was about $2 \mathrm{~L}$. Ants were reared in artificial nests, placed in $3 \mathrm{~L}$ recipients (for more details, see Della Lucia et al., 1993). Humidity, temperature and light-dark (LD) cycles in the rearing room were $75 \pm 5 \%$, $25 \pm 2{ }^{\circ} \mathrm{C}$ and 12:12 LD, respectively. Each nest had access to a foraging arena $(30 \mathrm{~cm} \times 20 \mathrm{~cm})$ where leaves and petals from flowers, as well as water were supplied daily. Behavioural tests were conducted with workers from four colonies (I, II, 
III, IV) and chemical tests were performed with workers of three colonies (I, II, III) due to the death of colony IV.

\section{Behavioural tests}

\section{Discrimination of pupae and larvae}

The methodology used in the bioassays with the brood was modified from Araújo et al. (1996). Colonies were deprived of food (leaves) for a $24 \mathrm{~h}$ period prior to the test. This procedure enabled a faster behavioural response of the workers. Larvae and pupae of four colonies were used. The brood of each colony was removed from the fungus garden and isolated in a Petri dish. Fifteen minutes later, the minimum time necessary for the ants to settle, either larvae or pupae were offered to workers on a glass slide marked with non-toxic ink in order to distinguish a nestmate from a nonnestmate. Positions of the slides were modified for each bioassay to avoid conditional behaviour of the workers. We conducted 54 replications for treatments with larvae (The number of replications is in parentheses) $[\mathrm{I} \rightarrow \mathrm{II}(5), \mathrm{I} \rightarrow \mathrm{III}(5), \mathrm{I} \rightarrow \mathrm{IV}$ (5), II $\rightarrow$ I (4), II $\rightarrow$ III (4), II $\rightarrow$ IV (4), III $\rightarrow$ I (5), III $\rightarrow$ II (5), III $\rightarrow$ IV (4), IV $\rightarrow$ I (4), IV $\rightarrow$ II (4), IV $\rightarrow$ III (5) and 54 for the control (I $\rightarrow$ I (13), $\mathrm{II} \rightarrow \mathrm{II}$ (14), III $\rightarrow$ III (14), IV $\rightarrow$ IV (13)]. Fifty three replications were conducted with pupae in a 20 min interval. Three types of workers' behaviour occurred: 1. acceptance; the brood was transported to the interior of the nest; 2 . rejection; the brood was transported to the trash pile; 3 . indeterminate; after $20 \mathrm{~min}$, the workers remained agglomerated around the brood, however they neither transported it inside the nest, nor transported it to the trash. We considered discrimination as the acceptance or rejection of the brood and t-test and $\chi^{2}$ were used for data analysis.

\section{Discriminatory ability in adult workers}

In order to estimate recognition between ants, we used aggressiveness tests. The bioassay consisted of encounters in a neutral arena (Petri dish $90 \mathrm{~mm}$ in diameter) between three workers and one marked with a colour dot on the abdomen that served as the test ant.

For 3 min (until the first physical contact with the marked ant), we recorded the reaction of the three ants to the marked ant according to the following aggression index: $0=$ non-aggressive interaction (antennal contacts, trophallaxis and allogrooming), $1=$ threat as indicated by mandibular opening and curling the abdomen, 2 = biting, 3 = fight and reciprocal mutilation. The frequencies and duration of each behavioural component were recorded using computer ODlog software and the overall aggressiveness $(A I)$ shown in each encounter was calculated as follows (Errard \& Hefetz, 1997):

$A I=\frac{\sum_{i=1}^{n} A I i * t i}{T}$

where A.I.i represents the aggression index, $t i$ the duration of each act, and $\mathrm{T}$ the total interaction time.

Before each encounter, the marked ant was allowed to acclimate by remaining isolated inside a glass tube placed in the center of the Petri dish. Each encounter began by removing the glass tube and recording the reaction of the ants towards the marked worker (nestmate or non-nestmate). In the control encounters, the four ants were nestmates (one marked) and were used to observe that marking the ant with a colour dot did not affect behaviour of the other ants (visual cues), as well as to establish a baseline behaviour before each test and overcome individual variability in the different tests. The Petri dish was lined with filter paper that was changed after each test and individuals were tested only once in a given encounter to avoid the possible effects of familiarization.

We conducted 48 replications for the treatments $(\mathrm{I} \rightarrow \mathrm{II}, \mathrm{I} \rightarrow \mathrm{III}, \mathrm{I} \rightarrow \mathrm{IV}, \mathrm{II} \rightarrow \mathrm{I}, \mathrm{II} \rightarrow$ III, II $\rightarrow$ IV, III $\rightarrow$ I, III $\rightarrow$ II, III $\rightarrow$ IV, IV $\rightarrow$ I, IV $\rightarrow$ II, IV $\rightarrow$ III; we conducted four replications for each type of encounter) and 48 for the control $(\mathrm{I} \rightarrow \mathrm{I}$, II $\rightarrow$ II, III $\rightarrow$ III, IV $\rightarrow$ IV; twelve times in each colony). The data were analyzed by Analysis of Variance (ANOVA).

\section{Fungus discrimination}

Concolonial and allocolonial broodless fungus pieces of $100 \mathrm{mg}$ were offered on glass slides to the colonies on the foraging arena. These fungus portions were also deprived of workers. A total of 32 replicates per colony were performed as treatment ( $32 \times 4=128$ tests $)$ and 32 replicates per colony were performed as control ( $32 \times 4=128$ tests). A total of 256 bioassays were 
conducted and results were submitted to the Mann Whitney's U test at $5 \%$ of significance.

The time for initial fungus pick up and for terminating fungus transport were recorded. For a maximum of $70 \mathrm{~min}$, the behaviour of workers was observed, resulting either in the transport of the fungus to the nest (= acceptance) or in the transport to the trash piles (= rejection), following Viana et al. (2001).

\section{Chemical analysis}

Regarding extraction, each worker (major, media and minor), brood (larvae and pupae) from 3 colonies were killed by freezing. Each ant's cuticular compounds were extracted by immersion in $2 \mathrm{~mL}$ of pentane for $10 \mathrm{~min}$. Larvae and pupae were immersed for $2 \mathrm{~min}$. to ensure that only cuticular substances were extracted. Fungus extracts $(250 \mathrm{mg}$ by vial) were obtained using the same methodology, but were immersed in dichloromethane.

Each extract was evaporated and subsequently redissolved in $50 \mu$ of pentane of which $1 \mu \mathrm{l}$ was injected into an on-column Varian 3300 GC equipped with a CPSil 5 capillary WCOT Chrompack column $(25 \mathrm{~m}, 0.25 \mathrm{~mm}$ Internal Diameter) that was temperature programmed from $80{ }^{\circ} \mathrm{C}$ to $280{ }^{\circ} \mathrm{C}$ at $5{ }^{\circ} \mathrm{C}$ per minute and then held at $280{ }^{\circ} \mathrm{C}$ for $20 \mathrm{~min}$. Quantification was done by peak integration using an Enica integrator. The different peaks were recorded, numbered and used for chemical analysis. For each profile (cuticular individuals or fungus surnagent), the relative value of each peak with respect to the total was calculated and shown as a percentage. Only peaks with a relative intensity above $1 \%$ were used for analysis.

We then used a hierarchical cluster analysis (Ward's method, Euclidean distance, Statistica for Windows 95 () and a discriminant analysis (Statistica for Windows 95 (C) to estimate the similarity (or divergence) between the chemical profiles of the different parts of each colony. Statistical analysis was performed on 54 extracts [18 extracts by colony (3 major, 3 media, 3 minor, 3 pupae, 3 larvae and 3 fungus) and this was replicated for the 3 colonies] and a total of 31 peaks.

\section{RESULTS}

\section{Behavioural tests}

\section{Discrimination of pupae and larvae}

The majority of the brood (55 to 62\%) used in the bioassays was accepted by the receiver colonies, regardless of being nestmates or nonnestmates. There was no difference in acceptance between nestmate and non-nestmate brood, in larvae $\left(\chi^{2}=47.1, \mathrm{p}=0.231\right)$ and pupae $\left(\chi^{2}=40.76\right.$, $\mathrm{p}=0.130)$ (Figs. 1 and 2).

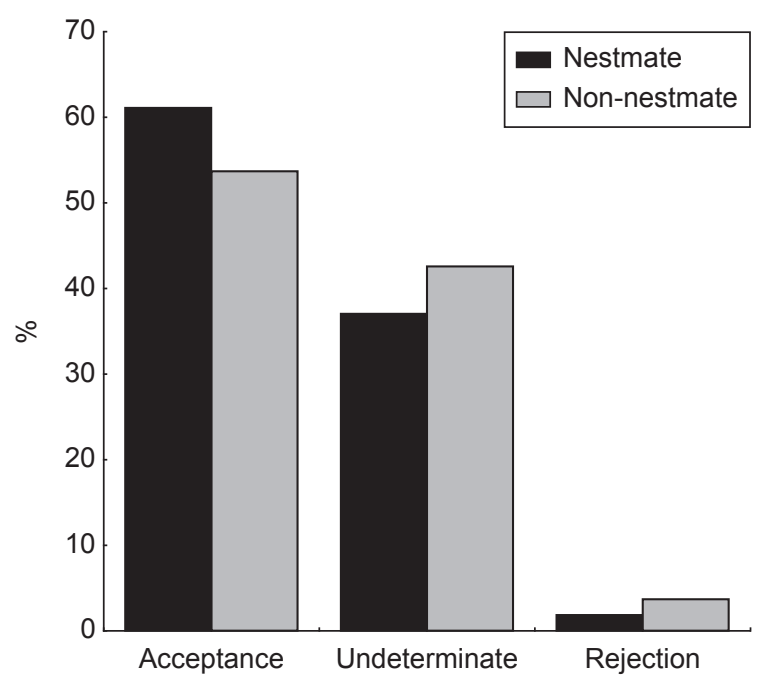

Fig. 1 - Behaviour of Acromyrmex laticeps nigrosetosus workers in the presence of concolonial or allocolonial larvae (expressed as acceptance or rejection percentage. There was no statistical difference between the groups $\left(\mathrm{p}<0.05, \chi^{2}\right)$ for each situation. $\mathrm{N}=54$ (non-nestmate) and $\mathrm{n}=54$ (nestmates). 


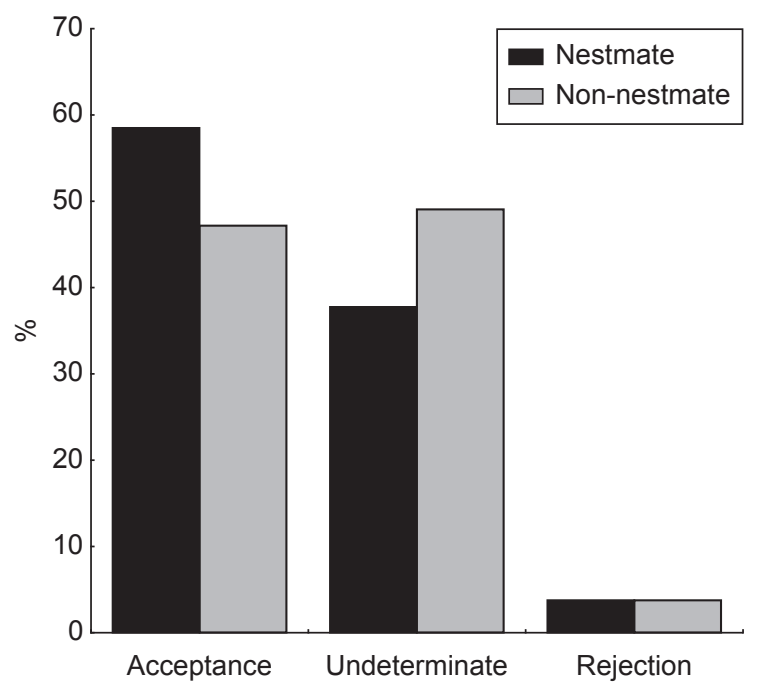

Fig. 2 - Behaviour of Acromyrmex laticeps nigrosetosus workers in the presence of concolonial or allocolonial pupae (expressed as acceptance or rejection percentage. There was no statistical difference between the groups $\left(p<0.05, \chi^{2}\right)$ for each situation. $\mathrm{N}=53$ (non-nestmate) and $\mathrm{n}=53$ (nestmates).

In the assays with larvae, the mean time for a colony to accept a nestmate (7.32 min) was not statistically different from that for a non-nestmate ( $p>0.05$, t-test). These results were similar to those obtained with pupae. It is interesting to point out that in $40 \%$ of the tests, the behaviour of the workers was undetermined since workers did not carry their brood to the nest nor did they transport it to trash piles. This means that both nestmates and non-nestmates had difficulties in discriminating the brood.

\section{Discriminatory ability in adult workers}

In all encounters, Ac. laticeps nigrosetosus workers from the control treatment did not react aggressively towards their marked nestmates. The only behaviour observed among workers was antennal contact. This observed behaviour was not different when the marked ant was a non-nestmate. $A I i$ between non-nestmates was as low $(A I i=0)$ as that between nestmates. Our data clearly indicated that workers of Ac. laticeps nigrosetosus could not discriminate between nestmate and non-nestmate.

\section{Fungus discrimination}

Workers of Ac. laticeps nigrosetosus retrieved to the nest both concolonial and allocolonial fragments of broodless fungus offered at the arena. There was $100 \%$ acceptance of either allocolonial or concolonial fungus in this study. However, the time of fungus transport to the nest was different ( $\mathrm{p}<0.05$, for $\mathrm{n}=32$ per colony and control tests) depending on the fungus origin. The average time (minutes) for nestmates to carry their own fungus was $16 \pm 12.18 \mathrm{~min}$. $(\mathrm{n}=128)$ whereas for allocolonial fungus this time was $36 \pm 22.93 \mathrm{~min}$ $(n=128)$.

\section{Chemical analysis}

\section{Chromatogram analysis}

Acromyrmex laticeps nigrosetosus workers possess a similar chemical profile that presents no qualitative difference as a function of the colony source. The mostquantifiable compounds (31 peaks) varied quantitatively between the different castes (major, media and minor) (Fig. 3a). In addition, no qualitative variation appeared between the different colonies for the pupae (Fig. 3b), larvae (Fig. 3c) and fungus extracts.

\section{Hierarchical cluster analysis (HCA)}

The schematic representation of the clustering obtained with the HCA algorithm on the mean chemical data of each category (major, media, minor, larvae, pupae and fungus) from each colony (1, 2 and 3) shows the nodes separating three groups (Fig. 4). The first node (26.94) separates (no 

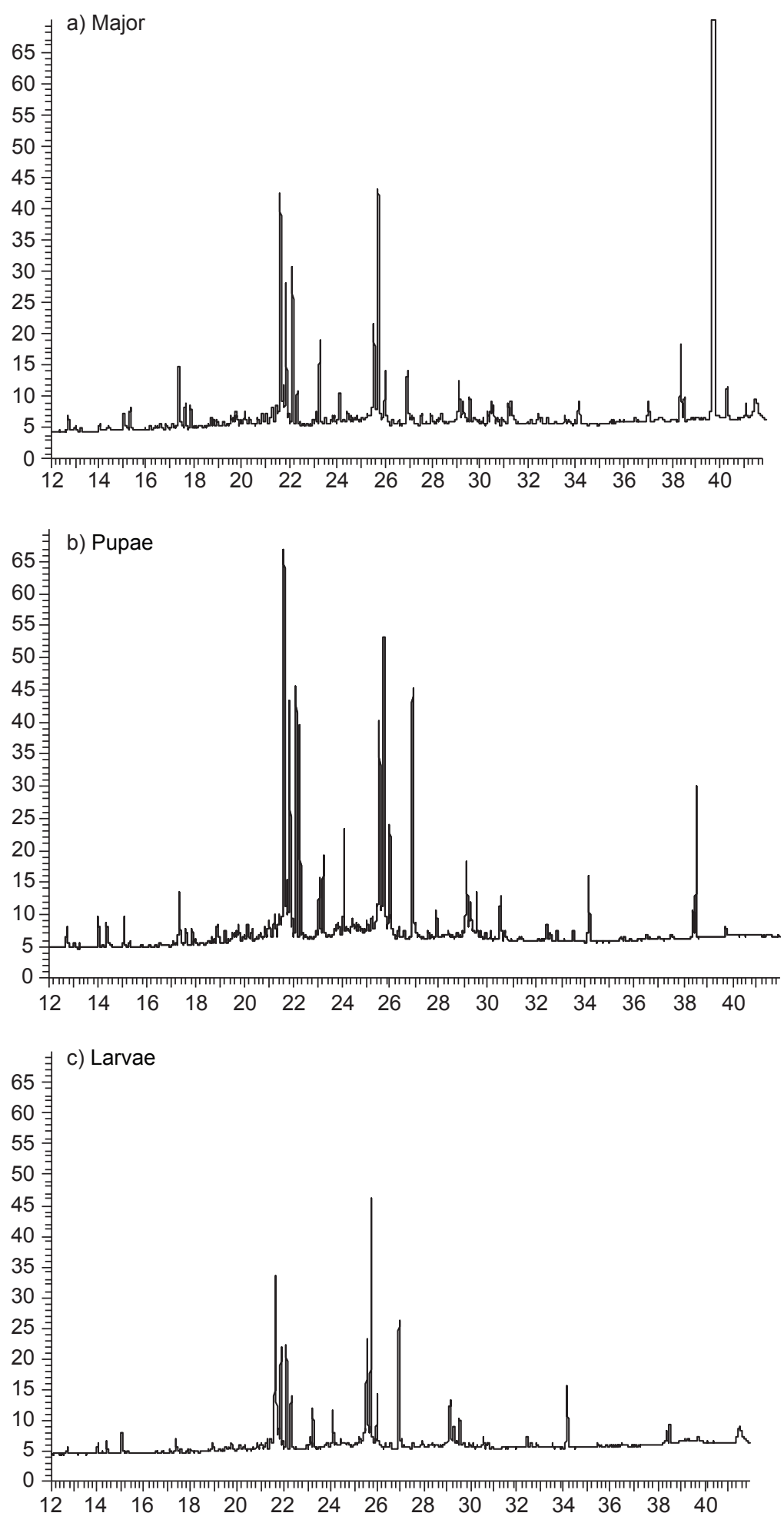

Fig. 3 - Gas chromatograms of the cuticular profiles of workers (major) and brood (pupae and larvae) of Acromyrmex laticeps nigrosetosus subspecies. a) major; b) pupae; and c) larvae. 


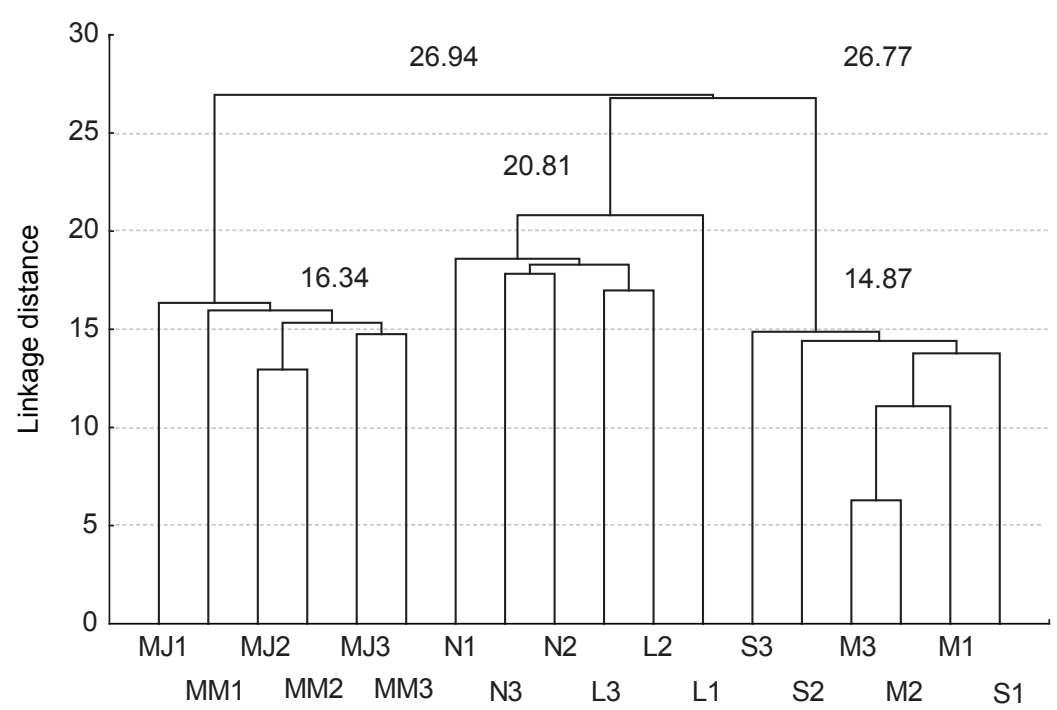

Fig. 4 - Hierarchical cluster analysis (Ward's method, Euclidean distances) conducted on the mean of the relative proportions (from the 3 colonies) of the 18 major peaks in Acromyrmex laticeps nigrosetosus workers (major: MJ1, MJ2, MJ3), media: MM1, MM2, MM3, minor: M1, M2, M3), A. laticeps nigrosetosus larvae (L1, L2, L3), A. laticeps nigrosetosus pupae (N1, N2, N3) and A. laticeps nigrosetosus fungus (S1, S2, S3).

significant difference) major (MJ1, MJ2, MJ3) and media (MM1, MM2, MM3) individuals from all other extracts (pupae, larvae, minor and fungus), and the second (26.77), which divides pupae (N1, $\mathrm{N} 2, \mathrm{~N} 3)$ and larvae (L1, L2, L3) from minor (M1, $\mathrm{M} 2, \mathrm{M} 3)$ and fungus (S1, S2, S3) situated at a lower but not significant level. This cluster analysis clearly reflects the proximity between the same elements of the different colonies. This detailed statistical analysis showed that the major and media ants clustered together (major/media $\mathrm{p}=0.43$ ) forming distinct groups according to (1) significantly to the brood castes (pupae/larvae $\mathrm{p}=0.12$; major/pupae $\mathrm{p}<0.0001 ;$ media/pupae $\mathrm{p}<0.001 ;$ major/larvae $\mathrm{p}<0.0001$; media/larvae $\mathrm{p}<0.0001$ ), (2) non significantly to the worker caste (major/minor $\mathrm{p}=0.25$; media/minor $\mathrm{p}=0.99)$ the minor being very close to the fungus (minor/fungus $\mathrm{p}=0.41$ ).

\section{Discriminant analysis}

A discriminant analysis was performed on the mean chemical data of each element of the three colonies (Fig. 5). Colonies were clustered in 3 not significantly distinct groups $(100 \%$ well clustered, $\left.\mathrm{F}_{26,6}=0.557 ; \mathrm{P}=0.86\right)$. It appeared that chemical profiles of each colony element are convergent with those of the other colonies.

\section{DISCUSSION}

The behavioural and chemical results of this study corroborate the hypothesis that recognition processes are based on the discrimination of colonial odour. Our results indicate that Ac. laticeps nigrosetosus societies are open, because workers show no aggressive behaviour towards alien conspecifics. In fact, intraspecific confrontations never exceeded antennal contact and non-nestmates interacted peacefully. No allogrooming or trophallaxis between nonnestmates was observed. Chemical profiles of Ac. laticeps nigrosetosus workers reveal only a slight divergence among them. The lack of aggressiveness in this subspecies is related to the lack of a uniform colony-specific odour as obtained in the chemical analyses. Behavioural tests with freshly collected field colonies revealed no aggression between nestmates and non-nestmates (unpublished data). This may explain the high density of colonies in the study area used by Araújo et al. (1997) and their foraging activity pattern without any hostility among workers from different colonies in the same foraging area in the field.

Since there was a significant difference between the time to retrieve the concolonial and 


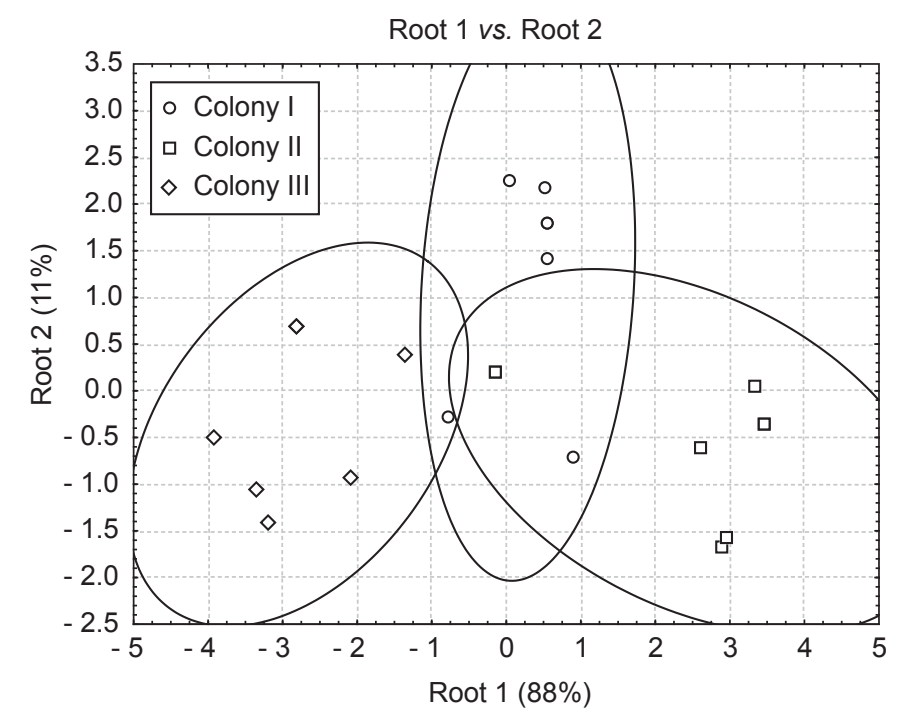

Fig. 5 - Discriminant analysis of chemical compounds (conducted on the mean of the relative proportions of 13 major peaks) for workers (major, media, minor), larvae, pupae and fungus from the different colonies of Acromyrmex laticeps. Distances between groups are not significant: colony I/colony II $p=0.91$; colony II/colony III $p=0.47$; colony I/colony III $p=0.80$. Ellipses are $95 \%$ confidence.

allocolonial fungus, it can be said that adult workers of Ac. laticeps nigrosetosus are able to discriminate allocolonial broodless fungus. However, they did not reject alien fungus unlike the results obtained by Viana et al. (2001). Although fungus containing a brood was not tested here, it can be hypothesized that the fungus would also be promptly transported to the nest by non-nestmates because there was no brood discrimination by workers of this subspecies. Future investigations should consider the possibility of allocolonial fungus acceptance increasing initial colony survival.

These findings are not compatible with those obtained by Araújo et al. (1996) with A. sexdens rubropilosa and by Viana et al. (2001) with Ac. subterraneus subterraneus. In both studies, workers were able to detect and reject the allocolonial brood, although there was a variation in the results with larvae and pupae. Reasons for these differences could probably be associated with the small size of Ac. laticeps nigrosetosus populations in contrast to those of Atta and even to other species of the genus Acromyrmex. Less aggressive behaviour can be considered advantageous to this subspecies since the cost of territorial defense and of greater aggressiveness may be very high if the defense force is small as in this case.

The fact that the colonies used in this experiment had been fed with the same type of leaves for two years may have influenced their discriminatory ability. Different diets influence the chemical profiles indirectly and consequently the recognition cues in Ac. subterraneus subterraneus (Richard et al., 2004). In the field Ac. laticeps nigrosetosus workers foraged basically on young Eucalyptus camaldulensis leaves obtained by climbing up the trees, cutting and transporting leaves to the nest (Araújo et al., 1997). According to these authors, the workers did not show trail fidelity while trails were poorly built and vegetation was abundant in the area. The role of diets on discrimination between nestmates and non-nestmate workers of Ac. laticeps nigrosetosus in the field deserves more investigation.

The strategy of non-discrimination of brood and allocolonial fungus acceptance by workers of this subspecies may represent higher probability of success and establishment. Observations of behavioural ecology should help in elucidating this point. 
Acknowledgments - We are grateful to Mara Garcia Tavares from the Biology Department at Federal University of Viçosa and Ricardo Della Lucia from the Forest Engineering Department Federal University of Viçosa for their suggestions on the manuscript. We also thank Patrizia D'Ettorre and JeanLuc Mercier (IRBI, Tours) for providing the ant extracts. This work was supported by CAPES-COFECUB, No 244-19982000 .

\section{REFERENCES}

ARAÚJo, M. S., DElla luCiA, T. M. C., ARAÚJO, F. S. \& BENTO, J. M. S., 1996, Discriminação da prole por operárias companheiras e não companheiras de ninho em Atta sexdens rubropilosa Forel, 1908 (Hymenoptera, Formicidae). Rev. Bras.Entomol., 40: 101-104.

ARAÚJO, M. S., DELlA LUCIA, T. M. C. \& MAYHÉNUNES, A. J., 1997, Levantamento de Attini (Hymenoptera, Formicidae) em povoamento de Eucalyptus na região de Paraopeba, Minas Gerais, Brasil. Rev. Bras. Zoo., 14: 323328.

BONAVITA-COUGOURDAN, A., CLEMENT, J-L. \& LANGE, C., 1989, The role of cuticular hydrocarbons in recognition of larvae by workers of ant Camponotus vagus: changes in the chemical signature in response to social environment (Hymenoptera: Formicidae). Sociobiology, 16: 49-74.

BONAVITA-COUGOURDAN, A., CLEMENT, J-L. \& LANGE, C., 1993, Functional subcaste discrimination (foragers and brood-tenders) in the ant Camponotus vagus Scop: polymorphism of cuticular hydrocarbon patterns. J. Chem. Ecol., 9: 1461-1477.

BOULAY, R., HEFETZ, A., SOROKER, V. \& LENOIR, A., 2000, Camponotus fellah colony integration: worker individuality necessitates frequent hydrocarbon exchanges. Anim. Behav., 59: 1127-1133.

CROZIER, R. H. \& DIX, M. W., 1979, Analysis of two genetic models for the innate components of colony odor in social Hymenoptera. Behav. Ecol. Sociobiol., 4: 217-224.

DELLA LUCIA, T. M. C., VILELA, E. F. \& ANJOS, N., 1993, Criação de formigas cortadeiras em laboratório. In: T. M. C. Della Lucia (ed.), As formigas cortadeiras, Folha de Viçosa, Viçosa.

ERRARD, C. \& HEFETZ, A., 1997, Label familiarity and discriminatory ability of ants reared in mixed groups. Insectes Soc., 44: 189-198.

FEBVAY, G., MALLET, F. \& KERMARREC, A., 1984, Attractivité du couvain et comportement des ouvrières de la fourmi Attini Acromyrmex octospinosus (Reich) (Hym. Formicidae). Act. Coll. Insectes. Soc., 1: 79-86.

HÖLLDOLBER, B. \& MICHENER, C. D., 1980, Mechanisms of identification and discrimination in social Hymenoptera. In: H. Markl(ed.), Evolution of social behaviour: hypothesis and empirical tests. Chemie Gmbh, Weinheim.

LAHAV, S., SOROKER, V., HEFETZ, A. \& VANDER MEER, R. K., 1999, Direct behavioural evidence for hydrocarbons as ant recognition discriminators. Naturwissenschaften, 86 : 246-249.

LENOIR, A., CUISSET, D. \& HEFETZ, A., 2001, Effects of social isolation on hydrocarbon pattern and nestmate recognition in the ant Aphaenogaster senilis (Hymenoptera, Formicidae). Insectes Soc., 48: 101-109.

RICHARD, F-J., HEFETZ, A., CHRISTIDES, J-P. \& ERRARD, C., 2004, Food influence on colonial recognition and chemical signature between nestmates in the fungusgrowing ant Acromyrmex subterraneus subterraneus. Chemoecology, 14: 9-16.

ROBINSON, S. W. \& CHERRETT, J. M., 1974, Laboratory investigations to evaluate the possible use of pheromones of the leaf-cutting ant Atta cephalotes (L.) (Formicidae: Attini) as a component in an attractive bait. Bull. Entomol. Res., 63: 519-529.

SOROKER, V., FRESNEAU, D. \& HEFETZ, A., 1998, Formation of colony odor in ponerine ant Pachycondyla apicalis. J. Chem. Ecol., 24: 1077-1090.

STUART, R. J. \& HERBERS, J. M., 2000, Nestmate recognition in ants with complex colonies: within- and betweenpopulation variation. Behav. Ecol., 11: 676-685.

VANDER MEER, R. K. \& MOREL, L., 1998, Nestmate recognition in ants. In: R. K. Vander Meer, M. Breed, M. Winston \& K. E. Espelie (eds.), Pheromone Communication in Social Insects. Westview Press, Boulder.

VANDER MEER, R. K., SALIWANCHIK, D. \& LAVINE, B., 1989, Temporal changes in colony cuticular hydrocarbon patterns of Solenopsis invicta: Implications for nestmate recognition. J. Chem. Ecol., 15: 2115-2125

VIANA, A. M. M., FREZARD, A., MALOSSE, C., DELLA LUCIA, T. M. C., ERRARD, C. \& LENOIR, A., 2001, Colonial recognition of fungus in the fungus-growing ant Acromyrmex subterraneus subterraneus (Hymenoptera: Formicidae). Chemoecology, 11: 29-36.

WAGNER, D., TISSOT, M., CUEVAS, W. \& GORDON, D. M., 2000, Harvester ants utilize cuticular hydrocarbons in nestmate recognition. J. Chem. Ecol., 26: 2245-2257.

WHitehousE, M. E. A. \& JAFFÉ, K., 1995, Nestmate recognition in the leaf-cutting ant Atta laevigata. Insectes Soc., 42: 157-166. 
